\title{
$\underline{\text { Towards a Gendered Political Economy of Water and Tourism }}$
}

\author{
Abstract \\ In many holiday destinations, the tourism industry exerts an enormous strain on water \\ supplies. This generates a range of social problems, not least because local inhabitants often \\ have to compete with the tourism sector over the access, allocation and use of water for their \\ personal and domestic needs. Nevertheless, there has been very little academic research on \\ the link between tourism and the impact of water scarcity on destination populations in \\ developing countries. While there is a wealth of literature on gender and tourism \\ development, such research has tended to focus on employment relations and tourism policy \\ and planning, neglecting ecological issues such as water. Drawing on original ethnographic \\ research conducted in Tamarindo, Costa Rica, in 2013, this paper makes a preliminary \\ attempt to address this gap in the literature by developing a gendered political economy \\ approach to water in tourism development.
}

Three key themes are identified from this research: the salience of intersectional inequalities of gender, class and nationality, in particular the different experiences of Nicaraguan women, Costa Rican women and women from the Global North; how the role of social reproduction is vital to understanding gender and water in Tamarindo due to enduring assumptions about women's perceived responsibility for water; and the gendered dimensions of conflicts over water. Such conflicts are highly gendered and contribute to reshaping of power relations in this international tourism destination. In the conclusions, we argue that our findings demonstrate the need to pay attention to both intersectionality and social reproduction, as well as to identify a future research agenda for developing a gendered political economy approach to tourism and water.

\section{Keywords}

Gender; water management; power relations; gendered political economy; intersectionality; social reproduction; Costa Rica 


\section{Introduction}

This paper addresses a gap in the current literature on tourism geographies by taking a gendered political economy approach to tourism and water. There is currently little research specifically addressing the inter-relationship between gender, water and tourism. Academic research on the impact of tourism-related water scarcity on destination populations is scarce (Gössling et al., 2012). Relevant issues include contamination, depletion and the unequal distribution of water generating conflict and societal instability (King, 2005). While there are high proportions of women working in the tourism industry worldwide (ILO, 2013), the relationship between tourism and gender (in)equality is complex and sometimes contradictory (Ferguson, 2011a). Political economy studies on gender and tourism have largely focussed on tourism and poverty reduction strategies (Tucker and Boonabaana, 2012) and how gender inequalities intersect with those of class, ethnicity and nationality (Vandegrift, 2008).

Research from the field of geography perspective shows how women have been marginalised in tourism development (Marshall 2001) and how tourism landscapes are gendered (Pritchard and Morgan 2000). Studies on gender and water, meanwhile, focus on water governance (Harris, 2009) and water campaigning (Laurie, 2010). However, gender issues are at present 'under-theorized and marginal' in mainstream water literature (Laurie, 2010, p. 172). This paper aims to bring these three strands of literature together to develop a political economy analysis of gender, water and tourism. Using the beach destination of Tamarindo in Costa Rica as a preliminary case study, we unpick the power inequalities between tourism enterprises and local residents; between men and women; and between women of different classes and nationalities. We are specifically concerned with how these intersecting inequalities play out in terms of the usage of, and attitudes to, water in Tamarindo.

Our gendered political economy approach draws on recent scholarship in this field, which explores the interactions between gendered power relations at the local and global levels. So too does it pay attention to the ways in which households, communities and markets are reconfigured through processes of global restructuring (see, for example, Bergeron, 2001; Bedford and Rai, 2010). While this study is limited in its capacity to address all the theoretical concerns of feminist political economy, we draw broadly on such an approach in order to analyse the structures of Costa Rican society and how the social relations, processes and outcomes of international tourism are influencing these and their relation to water 
resources. Two analytical lenses guide the exploration of these themes. First, we adopt an intersectional approach to understanding gender inequality (Crenshaw, 1991; McCall, 2005), addressing the ways in which differences between women affect their interaction with the political economy of tourism and water. Second, we focus on the political economy of social reproduction, acknowledging the interdependency between 'productive' (i.e. paid, formal) and 'reproductive' (unpaid, underpaid and informal) economic activity (England and Folbre, 2003; Elson, 2000). In our case study, this involves exploring gendered assumptions about women and water and how these play out in tourism destinations.

In order to do so, the paper begins with a critical literature review of three bodies of literature: tourism and water, gender and tourism, and water and gender, identifying the key gaps to be addressed. Next, we sketch the gendered political economy of tourism development in Tamarindo, drawing on both original research and insights from the existing literature. The third substantive section constructs a gendered political economy analysis of tourism and water in Tamarindo. Drawing on ethnographic research, it explores a number of themes: the role of social reproduction in shaping the dynamics of gender, water and tourism; how the relationship between gender, tourism and water is mediated through intersecting hierarchies such as gender, class and nationality; and the gendered politics of protests around tourism-related water conflicts. We conclude by setting out some further research questions inspired by this preliminary case study.

\section{Constructing a political economy of gender, tourism and water}

Despite access to water being a key indicator of progress towards achieving the Millennium Development Goals and in spite of the increasing importance of tourism in developing countries, there has not been substantive academic research on the link between tourism and the impact of water scarcity on destination populations (Essex, Kent and Newnham, 2004). Where such research has been conducted, it has tended to focus on Australia (Crase et al., 2010; Lehmann, 2009; Pigram, 2001) and the Mediterranean (De Stefano, 2004; Essex et al., 2004; Garcia and Servera, 2003; Kent, Newnham, and Essex, 2002; Rico-Amoros, OlcinaCantos, and Sauri, 2009; Tortella and Tirado, 2011). Research on developing country contexts is sparser, with the exceptions of Bali (Cole, 2012 and 2014), Honduras (Stonich, 1998) and Zanzibar (Gössling, 2001). A recent article by Gössling et al. (2012) provides a quantitative overview of the impact of tourism on water use, arguing that spatial and temporal aspects, such as seasonality, changes in water quality and competing water uses, need to be 
taken into account. A focus on the destination level is still required, particularly in developing country contexts, in order to explore the multi-dimensional impact of tourism water use on local communities and ecosystems (Cole, 2014). Studies have shown that the per capita use of water by tourists far exceeds that of locals (Crase, 2010; De Stefano, 2004). Overall, highend and luxury tourism establishments tend to consume greater volumes of water than smaller guesthouses (Deng and Burnett, 2002; Gössling, 2001; Gössling et al., 2012).

Such disproportionate water consumption by tourism establishments as compared to local households has a range of different impacts on local communities - both environmental and socioeconomic. Pressure on water resources is 'directly contributing to water scarcity and inequity' (Tourism Concern, 2012, p. 4), posing a direct threat to people's right to health while exacerbating existing poverty and generating conflict and societal instability (King, 2005; OECD/UNEP, 2011; Cole, 2012). In Bali, incremental privatisation has resulted in locals being forced to buy lower quality drinking water from unregulated sources; moreover, competition for water between tourism and agriculture means the loss of paddy and the loss of 'a way of life and important part of Balinese identity', as well as threatening Bali's tourism landscape and aesthetics (Cole, 2012, p. 1233). In terms of gender issues in water and tourism, there is currently very little research available. Exceptions include AlonsoAlmeida's (2012) study of women hotel managers in Morocco and their water consumption practices. However, to date, there has been no research which engages explicitly with the gendered power dynamics involved in water stress and water scarcity through tourism development.

This is the case despite the pivotal position women occupy in the tourism sector worldwide. Women make up 55.5\% of the work force at global level and up to $70 \%$ at the regional level. The opportunities for employment vary greatly between regions and are culturally defined in North Africa, for example, the workforce is almost entirely male (ILO, 2013). The bulk of extant research shows that women predominantly occupy lower status, lower skilled and lower paid positions (UNWTO and UN Women, 2011). Early research demonstrated how tourism is built on human relations and thus impacts and is impacted upon by global and local gender relations (Swain, 1995), constructing an argument for a more gender aware framework to understand tourism processes (Kinnaird and Hall, 1996). Subsequent studies have addressed the gender dimensions of employment in tourism (Sinclair, 1997; Vandegrift, 2008); gendered tourism imagery (Pritchard and Morgan, 2000; Marshment, 1997); sex 
tourism (Truong, 1990; Enloe, 1989; Sanchez Taylor, 2001, 2006 and 2010; Dahles and Bras, 1999) and female consumers (Frew and Shaw, 1999; Kim et al., 2007).

A key debate concerns the extent to which women's participation in the tourism workforce whether formal or informal - can be considered to redress unequal power relations or contribute to empowerment (Scheyvens, 2002; Ferguson, 2011a). While some studies show how participation in tourism challenges traditional gender roles (Gentry, 2007; Tucker, 2007; Nyaupane et al., 2006), others have cautioned against the limits of such empowerment. It has been suggested that these need to be contextualised within local notions of self-worth (Megarry, 2008) or that such empowerment is limited to the realm of income-generation (Ferguson, 2010a). Additional concerns include the high levels of unpaid work carried out by women in the tourism sector as 'contributing family workers' in tourism enterprises (UNWTO and UN Women, 2011; Ferguson, 2013). A range of authors have looked at the unsocial hours and high workloads in tourism employment and how this leads to unhealthy work life balances (Wong and Ko, 2009) and work-family conflicts (Karatepe and Uludog, 2007). However, few have taken a specifically gendered view of the problem, albeit with some exceptions such as Ferguson's (2010b) study of the impact of tourism development in Costa Rica and Belize on relations of social reproduction. A further concern of gender and tourism literature is the need to explore the ways in which tourism development affects different women in different ways. For example, as Vandegrift (2008) alludes, the classic dichotomy of 'first world' consumer and 'third world' producer obscures modern day realities. In her Costa Rican study, many transnational migrants from the Global North are owners of tourism businesses and also the preferred workers in many roles such as reception and sales. In light of this research context, this brief literature review demonstrates the salience of focussing on both social reproduction and intersectionality while analysing water and tourism in Costa Rica.

Finally, research on gender and water also makes a substantive contribution to our analysis and offers further insights into the core questions of social reproduction and intersectionality. While there is agreement that the social relations of water are poorly understood (Tortajada 1998; Crow and Sultana 2010; Truelove 2011) it is clear that historically women have been fundamental in the provision and management of water at household and community levels and that if daily practice is examined gender relations interact with class, material inequalities and other social power relations resulting in inequality in water security and access. While so 
frequently women and girls take responsibility to provide water men frequently own the productive assets, make decisions in government offices and communal institutions.

However, as Marshall (2010) explores, women's roles are changing and responsibilities are being renegotiated. As such, the majority of literature on women and water has been concerned with 'how to involve women more fully in water institutions and governance, as well as offering suggestions as to the value of doing so, whether for sustainability, equity or other concerns' (Harris, 2009, p. 391). At the same time as this growing field of research on women and water has emerged, gender has become an important feature of water campaigning, with women taking centre stage in struggles over water management issues. A wide range of networks and campaigning organisations now operate with a 'shared vocabulary around the importance of gender [...] irrespective of whether or not the different actors share feminist criteria' (Laurie, 2010, p. 178). Yet, despite this growing awareness of the role of women in water, 'most water sector decisions continue to be made based on the false assumption that they are gender neutral, that the population is a homogenous whole, and that benefits reach everyone equally' (Dávila-Poblete and Nieves Rico, 2005, p. 49).

While there is substantive research on women and water, on the whole gender issues remain 'under-theorized and marginal' in mainstream water literature (Laurie, 2010, p. 172), with a number of key pitfalls. Through a narrow focus on the involvement of women - as opposed to gendered power relations - such work tends to obscure the broader power dynamics at work in processes of the neoliberalization of water (Harris, 2009, p. 391). Two key insights from the work of Ahlers and Zweeten (2009) on gender and water are particularly illuminating for the purposes of our study. First, we are concerned with 'the power dynamics underlying resource allocation with gender inequality being a critical structuring force in this' (Ahlers and Zweeten, 2009, p. 411). Second, we follow the notion that feminist strategies in water politics should not just seek to 'equalize', but rather to construct possibilities for seeing beyond 'women' (Ahlers and Zweeten, 2009, p. 417). Following the literature on gender and water, our research aims to 'engage with how experiences, discourses and policies of water are gendered, and how gender is created through processes of engagement, use and control of water resources' (O'Reilly et al., 2009, p. 381). In order to do so, we suggest that an intersectional approach to the analysis of power relations is essential for exploring the dynamics at work in processes of water governance in tourism communities, as elaborated in more detail later in the paper. We now go on to sketch the background to the case study of 
Tamarindo, Costa Rica, before turning to our detailed approach to the gendered political economy of tourism and water.

\section{The Context: Tamarindo, Costa Rica}

Costa Rica was chosen as the pilot country in which to develop a gendered political economy approach to tourism and water largely because of its long history of tourism development and high proportion of women $(58.4 \%)$ in the tourism workforce (ILO, 2013). On first reading, it appears that Costa Rica would be unlikely to experience a marked gendered impact from water scarcity due to tourism. It is one of the most affluent and democratic countries in Latin America, one which sells itself as a tropical green/eco destination; it has relatively high aggregate gender indicators (Chant, 2008); and it only uses $2.5 \%$ of its available water resources (AyA and OPS/OMS, 2000; Food and Agriculture Organisation (FAO), 2000). However, reports of women protesting about tourism's over-use of water suggest that a gendered reading of tourism and water in Costa Rica is timely and pertinent. The two million tourists that visit Costa Rica every year (ICT, 2010) generate about $11.4 \%$ of employment and visitor exports represent $15 \%$ of the country's total exports (WTTC, 2013). Tourism is set to become the country's largest employer, with coastal tourism forming an especially important part of Costa Rica's tourism product (Lizano, 2011, p. 10-12). Over half the jobs generated are in rural areas, mostly in Guanacaste, the Pacific and Caribbean coasts. Emerging in the 1980s, tourism development policy in Costa Rica was initially premised on creating an enabling environment for foreign direct investment. While there are a number of large scale projects by multinational hotel chains, currently small and medium-sized enterprises make up $80 \%$ of the tourism sector. Moreover, Costa Rica's tourism industry is primarily, characterised by its appeal to 'niche' markets such as adventure tourism and nature tourism.

The distribution of both Costa Rica's population and its water is not even. In some areas, water is notably scarce. A 2009 report by the UN Human Rights Council reported that Costa Rica had still failed to get to grips with such problems, to the detriment of human rights (UN Human Rights Council, 2009). Although Costa Rica has one of the highest coverage ratios of drinking water for its population (>95\%) in Latin America (WHO and UNICEF, 2008), disparities in access to water between urban and rural areas persist and drinking water deprivation is increasingly contributing to child poverty (ECLAC, 2013). In Guanacaste Province, water scarcity is due primarily to competition, excess pollution, the dry climate and 
a lack of adequate resource development. In 1990, severe scarcity by 2000 was predicted given population and economic growth (Calvo, 1990). Conflicts have ensued, with one recent study identifying 65 significant water conflicts in Guanacaste between 1997 and 2006 (Kusdaz, 2012).

Tamarindo, a beach destination on the North Pacific Guanacaste Coast, was selected as the case study for this paper (see Figure 1). It has grown rapidly since the 1970s and is already experiencing acute water stress during the dry season. The research also builds on previous studies concerning women, migration and poverty based on examinations of the same region (Chant, 2008, 2006 and 2000).

\section{Insert Figure 1 about here}

Based on the National Institute Statistics and Censuses (INEC, 2012) data, the district of Tamarindo covers $123 \mathrm{~km} 2$ and includes the neighbouring settlements of Villa Real and Santa Rosa. It has a population of 6,375, a quarter of whom were born outside Costa Rica. Nearly $26 \%$ have no national insurance, $5 \%$ because they are unemployed and $20 \%$ because they are illegally employed. These figures obscure the presence of unemployed illegal migrants from Nicaragua and other countries, as discussed in more detail below. Costa Rica has the highest levels of migration of any Central American country, $75 \%$ of which is from Nicaragua (OECD, 2009). Most of those who lived in Tamarindo originally, and those who work in Tamarindo, live in the neighbouring villages of Villa Real and Santa Rosa. Before the late 1970s, Tamarindo was a remote village, only accessible on foot or by horse. Once a few backpackers and surfers began to stay in the destination's only small hotel, restaurants and lodges followed, built by lovers of peace and tranquillity from the capital, San José. Ten years later, a road was built and development began, reaching a frenzy between 2005 and 2008. A great deal of the later development was in real estate and residential tourism, resulting in a large number of condominiums (van Noorloos, 2011). There are now 64 registered hotels with a total of over 1600 rooms, including three large hotels with 200+ rooms each, eight medium sized establishments with 30 - 100 rooms, and the rest comprising small lodges. The development of Tamarindo corresponds with stages in the Tourism Area Life Cycle proposed by Butler (1980). 
In the 1970s, water for the area's sparse agricultural population came from artesian wells. The Costa Rican state owns all the country's underground water resources and grants access and withdrawal rights. In urban areas, the autonomous state institution for water and sanitation (AYA) supplies water, including to half of Tamarindo. Across the country, over 1,000 voluntary, community-based drinking water organizations (ASADA) provide water to $60 \%$ of the rural population (Madrigal et al., 2011). Tamarindo's ASADA, established in 1977, supplies half of Tamarindo. As with other ASADA, it works within the framework of rules and strict guidelines provided by the government, including a 50-50 male-female representation on its board. Madrigal et al. (2011) discuss the considerable variation in the performance of the different ASADA, noting that, in Tamarindo, they have received a number of awards for their efficient, constant, clean supply. However, both AYA and ASADA obtain their water from the same aquifer, which is limited and is starting to show signs of salt water intrusion.

Gender dynamics in Tamarindo and Guanacaste differ somewhat from the Costa Rican norm. Females are the head of $31 \%$ of households, whereas nationally this figure is $28 \%$ and has doubled since 2005 (Chant, 2008). As it is a marginal region, men in Guanacaste have traditionally migrated to find seasonal work. Coupled with a culture of multiple partners and alcohol consumption, the concept of the family in Guanacaste 'has always been a rather fragile entity and a source of struggle for women and children' (Chant, 2000, p.204). The region has a high number of births 'out of wedlock' (approximately 60\%) and serial consensual unions and female headed households are the norm. Tourism has brought employment and autonomy for many women, but their independence has reduced the role of male breadwinners and with it their power; consequently, tourism growth has affected ideas of masculinity and femininity in many Costa Rican tourism communities (Chant, 2000; Ferguson, 2011b). Much women's work in the region is seasonal, informal (approx. 50\%) and their mean earnings in hotels and restaurants are only $64 \%$ of male earnings in the sector (Chant, 2008). The 'feminisation of poverty' in the region 'is about increased unevenness of inputs to household survival between men and women' (Chant, 2008, p. 81). As Vandegrift (2008) suggests, while tourists surf, lie on a beach, dine-out or take tours, women perform the majority of labour that enables their daily experiences. Since construction halted in Tamarindo in 2008, job opportunities for men have shrunk; the only fields of work that remain are security, gardening and taxi driving. Across the tourism sector in Costa Rica, women make up over half (58.4\%) of the workforce (ILO 2013: 39). However, this masks 
variation across different regions, and does not account for what kinds of labour are being performed. In the case study community, Tamarindo, women do make up the majority of the workforce. However, this needs to be further broken down by nationality and socioeconomic status. Many front-line service and management jobs in tourism are held by women from North America and Western Europe. In contrast, the lower paid and more menial tasks such as cleaning and other domestic work are performed by Nicaraguan migrant women, who make up the bulk of the Tamarindo tourism workforce. Local Costa Rican women tend to work in more professional or clerical positions in the public and community sector, for example in the ASADAs and community organisations. Bearing in mind such dynamics at play in the region, we now go on to sketch a more detailed picture of the specific case study.

\section{Gender, water and tourism in Tamarindo}

The interview process revealed a wealth of insight into the separate areas of gender, tourism and water. However, specific information on the intersection between the three areas - the focus of this paper - was scarcer. In part, this is due to the pilot nature of this study and the fact that the research questions were being tested for the first time. As such, despite the rich information gathered, in this paper we focus only on those aspects which explicitly address the tourism-water-gender nexus.

Tourism in Tamarindo has followed a similar unmanaged pattern as tourism in so many developing destinations, involving unsustainable resource use and unsustainable tourism and lack of regulation (see for example Cole, 2012 on Bali; Duffy, 2002 and Honey, 2008 on Costa Rica). Development in the destination was described by an official at the Costa Rican Tourism Board as 'out of control', 'exactly how tourism shouldn't be'. There are no locallyowned hotels and only three establishments are owned and managed by Costa Ricans. While some nationals manage tourism businesses - two own guesthouses and one a restaurant, enterprises which tend to be inherited from their fathers - they do not work as employees. When interviewed, one resident stated:

the community's people are not the ones that have developed the town in the past 30 years, because it is expensive to do and they do not have any money. They have sold their lands, wasted the money and then left without land or money. Now everything is 
super expensive. But I don't want to sell, because without the land and without the money you turn into a slave. ... and you have to conform to their regime.

This echoes previous research on tourism and land prices in Costa Rica (Ferguson, 2011a).

In terms of water, according to the Department of the Environment (MINEA), there are over a hundred illegal wells and a backlog queue of over 1,000 requests for wells and reports about illegal wells, but only one person in the office to deal with this responsibility. Although the ASADA would like to increase their coverage to encompass all those in Tamarindo, they are dependent on AYA for a permit to do so. The immense revenues generated by supplying tourism ventures with water means that AYA refuses ASADA permission to expand. Meanwhile, in the dry season, AYA 'cannot deal with peak demand, the supply can be interrupted for 6-7 or 10-11 hours per day, we use trucks to deliver water to hotels', the AYA chief engineer reported when interviewed. The tiny portion of residents dependent on AYA water are left no choice but to wait until their water flows again. The unclear procedures in Costa Rica - both in terms of the legal, regulatory framework and the various institutions involved - have garnered an equal amount of criticism (Vargas, 2008, p. 115). As seen in Bali, the lack of adequate tourism management, combined with political and regulatory factors such as the overlap of institutional mandates, a lack of resources and weak law enforcement, have led to water shortages. These have disproportionately affected women, specifically different women for different reasons, with very different outcomes, as discussed below.

The following discussion draws upon research in Tamarindo in June 2013. The research was conducted within the feminist methodological tradition, involving reflexivity and attention to the power dynamics of the research process (Tickner, 2007) and drew on feminist ethnographic methods (Aune, 2008). The forty-four participants included representatives from six governments departments and seven guesthouses and hotels. Five interviews were conducted with representatives working in ASADA and three working for civil society organisations or associations. Twenty-four local people were interviewed - sixteen women, eight men; thirteen worked in tourism and eleven did not - who were selected using a combination of snowball and purposeful sampling. Some participants fall into more than one category. 27 participants were Costa Rican, 10 were Nicaraguan and 7 were Westerners. The interviews, which were taped and later transcribed and manually coded around key themes, 
were carried out in participants' homes or workplaces, in either Spanish or English. While standard interview themes were used, questions were tailored to the particular circumstances and biographies of participants. The following section will develop a gendered political economy analysis of the research findings, centred around three of the key themes: social reproduction, intersectionality and conflicts over water.

\section{Social reproduction}

Work in Tamarindo follows gendered divisions of labour in the workplace and household, as stereotypes and expectations of women's and men's roles in social reproduction play into the gendered dynamics of tourism labour. These responses taken together include a mixture of local: from Tamarindo, Costa Ricans from other regions and Nicaraguan, respondents. The gendered views on water were common to all groups. The general manager of one of the major international hotels in the region suggested that women deal better with the varied demands that hotel work requires, they have more balanced personalities, are more easy going and able to deal with difficult customers. They are also more trustworthy, honest and confident - he would never hire men as maids! By contrast, $100 \%$ of maintenance and garden jobs went to men. As one Nicaraguan tourism worker, Sorocco, explained, she and her family are the hotel staff; while she and her daughters perform kitchen duties, cleaning and laundry, one of her sons works in maintenance. Both she and her daughter head their households and must go to work to support their large family; child care is relegated to a close relative or neighbour, a situation noted in other research on social reproduction in tourism destinations in Costa Rica (Ferguson, 2010b). Similarly, Michael, a 39 year old Nicaraguan who works in hotel maintenance, explained the course of his day. 'After coming back home, I drink coffee, read the bible and practice on my keyboard'. At 7 p.m., the family have dinner and he goes to sleep. His wife, meanwhile works from 4 to 10 p.m. at a Pizzeria, yet also carries out all household chores from cooking and cleaning to washing and ironing, with the help of their daughter. 'She must do all the housework before going to work'.

In terms of water, these findings about social reproduction are relevant because water was consistently perceived as a women's issue by both male and female respondents. The gender differences at work were also reflected in attitudes to water. As Aguilar suggests, water is culturally feminine, 'the space of water provision was a feminine space par excellence' (2005, p. 134). One local resident explained 'when there is no water men do not care'; 'You 
[women] can't do anything without the water, and if he is there, he is just watching TV'. Jessica, a housewife responsible for performing all her family's housework, echoed the sentiment: 'When there's no electricity [because of a cut] and [we] cannot use the pump to draw water from the well, the situation is hopeless... You cannot wash or cook or supply the needs of children,' Her husband claimed he also suffers the effects of cuts, as then 'there is no way to take a shower'. One male interviewee pointed out that 'Women are more concerned about water, men see water as a possibility of business, women see it as a need for the family'. Marjorie, a community leader, further explained:

The woman is the one who is every day at home, we are the ones that have to wash, to cook, we always have that culture that we use water all the time; and also the woman is feeling it more, because at the moment they have no water, if the man goes to work, only the woman knows, the pressure is on women, who is stuck at home.

As such, research on gender, tourism and water in Tamarindo demonstrates the salience of a focus on social reproduction when analysing the relationship between tourism and water.

\section{Intersectionality}

The gender dimensions of water and tourism in Tamarindo are shaped not only by feminised labour but also by global migration patterns, from neighbouring Central American countries, North America and Western Europe. The most predominant migrant flows to Costa Rica come from Nicaragua, in particular for tourism and construction work. Nicaraguan migrants represent a "new "tier" of workers, who tend to sleep in the lowest quality accommodation and work in hyper-flexibilised tourism activities such as construction (men) and handicrafts or paid reproductive services (women)' (Ferguson, 2010b, p. 869). A number of respondents offered reasons why relatively wealthy Costa Ricans do not work in tourism, such as: 'It's very hard to find local [Costa Rican] staff - they do not speak English, it's hard to find reliable people who are self-motivated. It's difficult to find people who will work at weekend or late shift' (Restaurant manager); 'The Costa Rican people do not want to start at the bottom; they do not like the physical work of gardening or positions like that. Costa Ricans do not want to work as hard as Nicaraguans' (Director of CARTURGA). This reflects broader discourses on the ways in which different nationalities and social classes interact with the tourism labour market in Central America (Ferguson 2011b; Vandegrift 2008).

Nicaraguan women in particular lacked any leisure time and security in their work, as the following cases demonstrate. 
Petronilla_is a Nicaraguan woman who has worked in Tamarindo for 5 years. Every day, between 5 a.m. to 1 p.m. she cleans, prepares breakfast and caters to hotel guests in a 'boutique hotel'. Although she has taken a class in food handling and preparation, she received no certificate because she is an illegal immigrant. She shares a four bedroom house with eleven relatives including two of her children, both of whom do not go to school.

Juana is a 46 year old Nicaraguan woman who cleans houses, condos and offices in Tamarindo between 7 a.m. and 5 p.m. every weekday. None of her employers has given her a contract, so if she gets sick, 'there's no way'. 'No-one pays me insurance,' she reported, 'nobody, nobody'. Relatives look after her children while she is at work.

By contrast, interviews suggested that Costa Rican women 'do not work'; those with children prefer to remain at home themselves rather than arrange for others to provide childcare while they work from 6 a.m. to 9 p.m. More research would be required to ascertain whether this was a realistic reflection of women's work in Tamarindo. Nevertheless, it is worth reporting as a common perception of what kinds of women work in tourism and the reasons for this. Women from Europe and the USA work in temporary positions, often illegally, as receptionists and waitresses. These are client facing, front-stage jobs - as Vandergrift (2008) suggests - where language and cultural understanding is shared with guests. Most are young and appearance is part of their employability. As Chant (2008) discusses, women over 40 are considered to have little chance of getting work because they may not be seen as attractive enough or as having the right image. All those interviewed saw their jobs as temporary - a way to finance travels, 'a break from the pressures at home', with 'enough time off to surf, which is what I love and I can't do it in Germany.' This group was young and without child care responsibilities, able to balance leisure and work more easily than Petronilla and Juana. Their discourses demonstrate the ways in which intersectional dynamics work to condition how time and social reproductive activities are distributed in tourism communities.

In addition to labour issues, the impact of water shortages and concerns surrounding quality is highly dependent on the social location of respondents. As Ahlers and Zweeten argue (2009, p. 419): 
What women and men do, need and want in relation to water is only partially shaped by gender, and is a function of complex social and political dynamics. These dynamics are clearly gendered, but in articulation with contingent socio-economic processes determining their livelihoods.

Poor water pressure was a common complaint from women residents of Tamarindo. While interruptions to water supply were a key problem during the tourism high season, at other times of year lack of water was not generally a problem. Nonetheless, issues arose concerning water quality which plays into the intersectional dynamics outlined in this section. The high mineral or chlorine content of water meant that those able to afford it - middle class Costa Ricans and migrants from the Global North - tended to drink bottled or filtered water, while low income Nicaraguan migrants were less able to afford this privatised solution. In addition, differences in attitudes to water use were notable. When considered through the lens of nationality, there is a clear contrast between migrant and Costa Rican women, on the one hand, and tourists staying in hotels and guesthouses on the other. One hotelier interested in greater water conservation explained 'We cannot control water people use in their room. All rooms used to have low flow shower heads but we had lots of complaints. [...] Americans want the water pressure, or they complain. [...] We need to give people what they are asking [for]'.

Nationality also proved a salient issue for tourism workers from outside of Costa Rica, as described above. None of the young female foreign workers were aware of Tamarindo's water problems and none seemed to particularly care. The German receptionist thought that towel usage 'was mad...one for by the pool for half an hour, another for the beach and then a couple of hours later another for by the pool...how many towels can one person use in a day? I don't know why we wash them, we could just dry them.' However, she had never voiced these concerns to her employers. Despite a growing environmental conscience among Europeans, these temporary sojourners were not in town long enough to challenge water usage. In summary, the interaction with water issues caused by tourism depends heavily on social location and is mediated by class, nationality and ethnicity. Yet gender issues still remain especially salient here due to women's assumed responsibility for water, as set out above. 


\section{Gendered conflicts over water}

The Nimboyores project constituted one of the most high profile conflicts over water in tourism development in Costa Rica. This case, recounted through a Youtube video (http://www.youtube.com/watch?v=rCj6YQC1m5I

http://www.youtube.com/watch?v=iFzrQVew7aI), highlights how women's activism prevented a multinational hotel chain from over-using a local water supply. It indicates how women used their labour to upset the international political economy and disrupt the power structures of international finance over local resources. When the Meliá hotel group tried to pipe water from the village of Lorena to a coastal development, the local community was not informed until mid-way through the project. One of our interviewees, María Rosa, had worked as a teacher in the capital San José and on her return became a member of the Lorena Community Association. María Rosa had organised the protest against Meliá's actions and stopped the project, believing it illegal and fearing the village would be left with insufficient water. She fought institutions at the local, provincial and, finally, the national level. During the eight year conflict, a senator had argued in favour of the pipeline as 'necessary' because the Melia group had already purchased materials for the project and might sue the government if they were prevented from carrying it out. Rosa María felt that 'the government only cared about the demand from Meliá and the communities could go to hell'. Institutional struggles were followed 'by protests, blocking the streets, and we sat on the Meliá's pipes for a month, so they could not begin construction'. The parties eventually accepted the allocation of a smaller quantity of water for the pipeline and, agreeing that this water would benefit the broader coastal community rather than solely tourism development (Kusdaz, 2012). This example reflects the power struggles between corporation and community over water distribution, becoming the focus for women's activism over water allocation in the region. Women are the driving force for change coalescing around the unequal power relations between multinational enterprises and communities over water allocation.

It is also worth noting that, while few Costa Rican women work in tourism in Tamarindo, they participated in the ASADAS and community development associations. By contrast, no Nicaraguan women were found to have participated in such activities. This participation 'has changed... at the cultural level....there has been a change in the structure, at the community level, women participate more; more women are now... involved, both socially and on water issues'. According to Marie Rosa, this is due to greater access to education and a change in 
the 'machismo' (male chauvinism). Similar feelings were expressed in the development association. As the (male) head of a local ASADA said, 'Women are almost always the ones that are there, that are active'.

Overall, women's participation in activism appears to be increasing. Of the six people interviewed who took on strong activist roles, five were women. The groups that have protested about water shortages due to tourism have been shaped by women, echoing findings on women's role in water campaigning in Bolivia (Laurie, 2010). One informant suggested that many men simply do not care, while others argue that the fight for water falls to women since they are the ones 'in the house'. These findings raise a number of interesting issues about the power dynamics of women's responsibility for water, as well as how organizing around these concerns may challenge or reinforce gendered power relations. We now turn to some final reflections on this pilot case study.

\section{Conclusions}

The findings of this pilot study lead to three tentative conclusions. First, as outlined above, water in Costa Rica (and in most developing countries worldwide) is considered to be the responsibility of women. This is primarily related to the gendered division of labour, which places water in the social reproductive realm and, therefore, outside of the concerns of the masculine sphere. These gendered discourses of water mean that women are disproportionately affected by water shortages and water quality issues related to tourism development. Moreover, the pervasive association of women with water crystallises gender roles and closes down space for negotiating the reallocation of social reproductive tasks. It is important to avoid the essentialism of much research on gender and water - and, indeed, gender and tourism - where women are assumed to be 'naturally' responsible for water provision and hospitality. While our research confirmed these assumptions about women's assumed responsibility for both water and hospitality in Costa Rica, future research must challenge such essentialist assumptions to explore disruptions of gendered power relations.

A second, and related, conclusion concerns the ways in which women use this perceived responsibility for water to organise around resistances to tourism development, as in the aforementioned Nimboyores project. As such, this case study demonstrates the ways in which social reproductive roles can be used to challenge the contemporary political economy of tourism development. Women are a force for change in the political economy of tourism, 
taking on the might of multi-nationals and shifting the power status quo. Third, as our findings show, a focus exclusively on women rather than a broader analysis of gendered power relations is problematic. A gendered political economy approach to water and tourism needs to pay close attention to both the specific context and trajectory of tourism development while conducting an analysis of intersecting inequalities such as gender, class, nationality and ethnicity in order to map the impact of tourism-based water issues more systematically. By exploring such issues through the lens of intersectionality, this study reveals how such experiences are shaped by class and nationality, while gender nevertheless remains a salient disciplining force for women in tourism communities.

In this paper, we have uniquely considered the water-tourism-gender nexus and addressed a hitherto neglected dimension of water shortages caused by tourism - namely, the socioeconomic dimensions thereof. By bringing a gender analysis to the foreground, our research goes beyond questions about tourism's environmental impact and explores the ways in which such an impact interacts with and (re)articulates inequalities, particularly gendered inequalities. However, as a preliminary case study, we are left with a number of questions that could shape a future research agenda in this area. First, an analysis is required of the gender dimensions of water consumption at all levels, not only in the case of water shortages or problems of access. Research could sketch a broad empirical picture of water use in tourism communities, mapping out gendered power relations in terms of usage, control and access. This would require an intersectional approach which explicitly acknowledges differences between women while paying attention to the salience of gender. Second, we need to develop more substantively the findings on the gender dimensions of activism and organising around tourism's impact on water supply and quality. This would build on the research in Costa Rica to explore the extent to which gendered power relations play out in resistance to the tourism sector, and how such acts challenge inequalities and contribute to empowerment for women. Finally, future research could focus more explicitly on the relationship between social reproduction, tourism and water. This would involve factoring in the unpaid work related to water and the extent to which the tourism sector increases or exacerbates such unpaid labour. We consider this paper a tentative first step in constructing a gendered political economy approach to tourism and water, with the overall aim of understanding how changes in water use spurred by tourism development reshape and restructure the political economy of households, communities and markets. 


\section{References}

Aguilar, L. 2005. Water as a source of equity and empowerment in Costa Rica. In V. Bennett, S. Dávila-Poblete and M.E. Nieves Rico (Eds.), Opposing Currents: The politics of water and gender in Latin America (pp. 30-49). Pittsburgh: University of Pittsburgh Press.

Ahlers, R., and Zweeten, M. (2009). The water question in feminism: water control and gender inequities in a neo-liberal era. Gender, Place and Culture, 16(4), 409-426.

Alonso-Almeida, M.D.M. (2012). Water and waste management in the Moroccan tourism industry: The case of three women entrepreneurs. Women's Studies International Forum, $35(5), 343-353$.

Aune, K. (2008). Feminist Ethnography. In J. O’Brien (Ed.), Encyclopaedia of Gender and Society (pp. 309-312). Thousand Oaks, CA: SAGE.

AyA (Instituto Costarricense de Acueductos y Alcantarillados) and OPS/OMS (Organización Panamericana de la Salud/Organización Mundial de la Salud). (2000). Agua potable y saneamiento de Costa Rica: Análisis sectorial. San José: AyA and OPS/OMS.

Bedford, K. and Rai, S. (2010). Feminists theorize international political economy. Signs, $36(1), 1-18$.

Bergeron, S. (2001). Political economy discourses of globalization and feminist politics. Signs, 26(4), 983-1006.

Butler, R. (1980). The conception of a tourism area life cycle evolution: implications for management of resources, The Canadian Geographer 21(1), 5-12).

Calvo, J. (1990) Water resources development in Costa Rica 1970-2000. Hydrological Sciences Journal, 35(2), 185-196.

Chant, S. (2000). Men in crisis? Reflections on masculinities, work and family in north-west Costa Rica. The European Journal of Development Research, 12, 199-218. 
Chant, S. (2006). Re-thinking the "feminization of poverty" in relation to aggregate gender indices. Journal of Human Development, 7(2), 201-220.

Chant, S. (2008). The curious question of feminising poverty in Costa Rica: The importance of gendered subjectivities. Gender Institute: New Working Papers Series, 22, 1-96.

Cole, S. (2012). A political ecology of water equity and tourism: A case study from Bali. Annals of Tourism Research, 39(2), 1221-1241.

Cole, S. (2014). Tourism and water: from stakeholders to rights holders, and what tourism businesses need to do. Journal of Sustainable Tourism, 22(1), 89-106.

Crase, L., O'Keefe, S., Horwitz, P., Carter, M., Duncan, R., Hatton Macdonald, D., Haslam McKenzie, F. and Gawne, B. (2010). Australian tourism in a water constrained economy: Research agenda. Gold Coast, Australia: CRC for Sustainable Tourism.

Crenshaw, K. (1991). Mapping the margins: Intersectionality, identity politics, and violence against women of color. Stanford Law Review, 43(6), 1241-1299.

Crow B and Sultana F 2010 Gender, class, and access to water: three cases in a poor and crowded delta. Society and Natural Resources: An International Journal 15:8, 709-724

Dahles, H. and Bras, K. (1999). Entrepreneurs in romance: tourism in Indonesia. Annals of Tourism Research, 26(2), 267-293.

Dávila-Poblete, S. and Nieves Rico, M. E. (2005). Global water and gender policies: Latin American challenges. In V. Bennett, S. Dávila-Poblete and M.E. Nieves Rico (Eds.), Opposing Currents: The politics of water and gender in Latin America (pp. 30-49). Pittsburgh: University of Pittsburgh Press.

De Stefano, L. (2004). Freshwater and Tourism in the Mediterranean. Rome: WWF Mediterranean Programme. 
Deng, S. and Burnett, J. (2002). Energy use and management in hotels in Hong Kong. International Journal of Hospitality Management, 21(4), 371-380.

Duffy, R. (2002). A Trip Too Far: Ecotourism, Politics and Exploitation. London: Earthscan.

ECLAC (Economic Commission for Latin America and the Caribbean). (2014). Social Panorama of Latin America 2013. Santiago, Chile: United Nations. Retrieved from http://www.eclac.cl/cgibin/getProd.asp?xml=/publicaciones/xml/8/51768/P51768.xmlandxsl=/publicaciones/fichai.xslandbase=/publicaciones/top_publicaciones-i.xsl\#

Elson, D. (2000). Gender at the Macroeconomic Level. In J. Cook, J. Roberts and G. Waylen (Eds.), Towards a Gendered Political Economy (pp. 77-97). Basingstoke: Macmillan Press.

England, P. and Folbre, N. (2003). Contracting for Care. In M.A. Ferber and J.A. Nelson (Eds.), Feminist Economics Today: Beyond Economic Man (pp. 61-80). Chicago: University of Chicago Press.

Enloe, C. (1989). Bananas, Beaches and Bases. London: Pandora.

Essex, S., Kent, M. and Newnham, R. (2004). Tourism development in Mallorca: is water supply a constraint? Journal of Sustainable Tourism, 12(1), 4-28.

FAO (Food and Agriculture Organisation). (2000). Costa Rica. Aquastat Country Profile. Rome: FAO.

Ferguson, L. (2010a). Interrogating 'gender' in development policy and practice: the World Bank, tourism and microenterprise in Honduras. International Feminist Journal of Politics, 12(1), 3-24.

Ferguson, L. (2010b). Tourism development and the restructuring of social reproduction in Central America. Review of International Political Economy, 17(5), 860-888. 
Ferguson, L. (2011a). Promoting gender equality and empowering women? Tourism and the third Millennium Development Goal. Current Issues in Tourism, 14(3), 235-249.

Ferguson, L. (2011b). Tourism, consumption and inequality in Central America. New Political Economy, 16(3), 347-371.

Ferguson, L. (2013, March). Social reproduction and 'contributing family workers' in global political economy: the case of tourism. Paper presented at the European Conference on Politics and Gender, Barcelona.

Frew, E. and Shaw, R. (1999). The relationship between personality, gender, and tourism behavior. Tourism Management, 20(2), 19311.

Garcia, C. and Servera, J. (2003). Impacts of tourism development on water demand and beach degradation on the island of Mallorca (Spain). Geografiska Annaler, 85A (3-4), 287300.

Gentry, K. M. (2007). Belizean women and tourism work: opportunity or impediment? Annals of Tourism Research, 34(2), 477-496.

Gössling, S. (2001). The consequences of tourism for sustainable water use on a tropical island: Zanzibar, Tanzania. Journal of Environmental Management, 61(2), 179-191.

Gössling, S., Peeters, P., Hall, C. M., Ceron, J.P. and Dubois, G. (2012). Tourism and water use: supply, demand and security. An international review. Tourism Management, 33, 1-13.

Harris, L. M. (2009). Gender and emergent water governance: comparative overview of neoliberalized natures and gender dimensions of privatization, devolution and marketization. Gender, Place and Culture, 16(4), 387-408.

Honey, M. 2008. Ecotourism and Sustainable Development: Who Owns Paradise? (2 ${ }^{\text {nd }}$ ed.). Washington: Island Press. 
ICT (Instituto Costarricense Turismo). (2010). Anuario Estadístico. San José: Costa Rican Government.

ILO. (2013). International Perspectives on Women and Work in Hotels, Catering and Tourism. Geneva: ILO. Retrieved from http://www.ilo.org/wcmsp5/groups/public/--dgreports/---gender/documents/publication/wcms_209867.pdf

INEC (National Institute of Statistics and Censuses of Costa Rica) (http://www.inec.go.cr)

Karatepe, O. M. and Uludag, O. (2007). Conflict, exhaustion, and motivation: a study of frontline employees in Northern Cyprus hotels. International Journal of Hospitality Management, 26(3), 645-665.

Kent, M., Newnham, R. and Essex, S. (2002). Tourism and sustainable water supply in Mallorca: a geographical analysis. Applied Geography, 22(4), 351 - 374.

Kim, D.Y., Lehto, X. Y., and Morrison, A. M. (2007). Gender differences in online travel information search: implications for marketing communications on the internet. Tourism Management, 28(2), 423-433.

Kinnaird, V. and Hall, V. (1996). Understanding tourism processes: a gender aware framework. Tourism Management, 17(2), 95-102.

King, M. (2005). Water and Violent Conflict. Paris: OECD. Retrieved from http://www.globalpolicy.org/images/pdfs/052605waterconflict.pdf

Kuzdas, C. (2012). Unpacking water conflict in Guanacaste, Costa Rica (GWF Discussion Paper 1242) Canberra: Global Water Forum. Retrieved from http://www.globalwaterforum.org/wp-content/uploads/2012/10/Unpacking-water-conflict-inGuanacaste-Costa-Rica-GWF-1242_.pdf

Laurie, N. (2010). Gender water networks: femininity and masculinity in water politics in Bolivia. International Journal of Urban and Regional Research, 35(1), 172-188. 
Lehmann, L.V. (2009). The relationship between tourism and water in dry land regions.

Proceedings of the Environmental Research Event, Noosa, Queensland, Australia.

Lizano, R. (2011). Futuro del desarollo turístico en los litorales de Costa Rica.

Ambientales, 42, 7-18.

Marshall, J. (2001). Women and strangers: issues of marginalization in seasonal tourism.

Tourism Geographies: An International Journal of Tourism Space, Place and Environment, 3 (2), 165-18

Marshment, M. (1997). Gender takes a holiday: representation in holiday brochures. In M.T. Sinclair (Ed.), Gender, Work and Tourism (pp. 16-34). London: Routledge.

McCall, L. (2002). The Complexity of intersectionality. Signs, 30(3), 1771-1800.

Megarry, K. (2008). Tourism and Kudumbashree: a Southern solution empowering women through tourism. In P. Burns and M. Novelli (Eds.), Tourism, Development and Growth (pp. 217-238). CABI.

Nyaupane, G., Morais, D. and Dowler, L. (2006). The role of community involvement and number/type of visitors on tourism impacts: a controlled comparison of Annapurna, Nepal and Northwest Yunnan, China. Tourism Management, 27(6), 1373-1385.

O’Reilly, K., Halvorson, S., Sultana, F. and Laurie, N. (2009). Introduction: global perspectives on gender-water geographies. Gender, Place and Culture, 16(4), 381-385.

OECD. (2009). Latin American Economic Outlook 2010. Retrieved from http://www.oecd.org/dev/americas/44535774.pdf

OEDC/UNEP (2011). Climate Change and Tourism Policy in OECD Countries. Retrieved from http://www.unep.fr/scp/publications or www.oecd.org/cfe/tourism 
Pigram, J. (2001). Water resources management in island environments: the challenge of tourism development. Tourism (Zagreb), 49(3), 267-274.

Pritchard, A. and Morgan, N. (2000). Constructing tourism landscapes - gender, sexuality and space. Tourism Geographies: An International Journal of Tourism Space, Place and Environment, 2 (2), 115-139

Rico-Amoros, A.M., Olcina-Cantos, J. and Sauri, D. (2009). Tourist land use patterns and water demand: evidence from the Western Mediterranean. Land Use Policy, 26(2), 493-501.

Sanchez Taylor, J. (2001). Dollars are a girl's best friend? Female tourists' sexual behaviour in the Caribbean. Sociology, 35, 749-764.

Sanchez Taylor, J. (2006). Female Sex Tourism: a contradiction in terms? Feminist Review, $83,42-59$.

Sanchez Taylor, J. (2010). Sex tourism and inequalities. In S. Cole and N. Morgan (Eds.), Tourism and Inequality: Problems and Prospects (pp. 49-66). Oxford: CABI.

Scheyvens, R. (2002). Tourism for development. Empowering Communities. Harlow: Pearson.

Sinclair, M. T. (1997). Issues and theories in gender and work in tourism. In M.T. Sinclair (Ed.), Gender, Work and Tourism (pp. 1-15). London: Routledge.

Stonich, S. (1998). The political Ecology of Tourism. Annals of Tourism Research, 25(1), 2554.

Stonich, S. C., Sorensen, J. H. and Hundt, A. (1995). Ethnicity, class, and gender in tourism development: the case of the Bay Islands, Honduras. Journal of Sustainable Tourism, 3(1), 128.

Swain, M. (1993). Women producers of ethnic arts. Annals of Tourism Research, 20(1), 3251. 
Tickner, J. A. (2005). What is your research program? Some feminist answers to international relations methodological questions. International Studies Quarterly, 49, 1-21.

Tortajada, C. (1998). Water supply and wastewater management in Mexico: an analysis of the environmental policies. International Journal of Water Resources Development 14:3, 327-337

Tortella, B and Tirado, D. (2011). Hotel water consumption at a seasonal mass tourist destination. The case of the island of Mallorca. Journal of Environmental Management, 92(10), 2568-2579.

Tourism Concern. (2012). Water Equity in Tourism: A Human Right - A Global Responsibility. London: Tourism Concern. Retrieved from http://www.tourismconcern.org.uk/uploads/Water-Equity-Tourism-Report-TC.pdf

Truelove, Y. 2011 (Re-)conceptualizing water inequality in Delhi, India through a feminist political ecology framework. Geoforum 42 (2), 143-152

Truong, T. (1990). Sex, Money and Morality: Tourism and Prostitution in South-East Asia. London: Zed Books.

Tucker, H. (2007). Undoing shame: tourism and women's work in Turkey. Journal of Tourism and Cultural Change, 5(2), 87-105.

Tucker, H. and Boonabaana, B. (2012). A critical analysis of tourism, gender and poverty reduction. Journal of Sustainable Tourism, 20(3), 437-455.

UN Human Rights Council. (2012) Report of the independent expert on the issue of human rights obligations related to access to safe drinking water and sanitation, Catarina de Albuquerque, Addendum: Mission to Costa Rica, June 2009. Retrieved from http://www.ohchr.org/Documents/Press/IE_2009_report.pdf 
UNWTO and UN Women. (2011). Global Report on Women in Tourism 2010. Madrid:

UNWTO. Retrieved from

http://dtxtq4w60xqpw.cloudfront.net/sites/all/files/pdf/global_report_on_women_in_tourism _2010.pdf

van Noorloos, F. (2011). Residential tourism causing land privatization and alienation: new pressures on Costa Rica's coasts. Development, 54(1), 85-90.

Vandegrift, D. (2008). “This isn't paradise I work here”: Global restructuring, the tourism industry and women workers in Caribbean Costa Rica. Gender and Society, 22, 778-798.

Waylen, G. (2000). Gendered Political Economy and Feminist Analysis. In J. Cook, J. Roberts and G. Waylen (Eds.), Towards a Gendered Political Economy (pp. 14-38).

Basingstoke: Macmillan Press.

WHO/UNICEF. (2008). Joint Monitoring Programme for Water and Sanitation. Retrieved from http://www.wssinfo.org/en/238_wat_latino.html

Wong, S. and Ko, A. (2009) Exploratory study of understanding hotel employees' perception on work-life balance issues. International Journal of Hospitality Management, 28(2), 195203.

WTTC (World Travel and Tourism Council). (2013). Economic Impact : Costa Rica 2013. Retrieved from http://www.wttc.org/site_media/uploads/downloads/costa_rica2013.pdf 